\title{
Phil Stong's State Fair
}

R O B E R T A. M C COW N

Undoubtedly, one of the most famous books in the Iowa Authors Collection is State Fair by Phil Stong. If you have not had the pleasure of reading this novel, perhaps a brief immersion into the historical background of the work and a condensed look at the facts and events in the life of the writer will enhance your enjoyment of the book.

The author of State Fair, Philip Duffield Stong, was born on January 27, 1899, near Pittsburg, Iowa, a village no longer found on maps. Pittsburg was on the west side of the Des Moines River in southeast Iowa's Van Buren county. Young Phil was the son of Benjamin and Ada Evesta Duffield Stong. Father Ben ran a general store in Pittsburg and then later a variety store in Keosauqua, the county seat of Van Buren County, where he was also postmaster.

Phil Stong went to grade and high school in Keosauqua and then to Drake University in Des Moines, Iowa's capital. At Drake he majored in English, minored in German, and wrote a senior thesis on the aesthetics of Schiller and Santayana. After graduation in 1919 he taught in the high school at Biwabik, Minnesota, a town on the Mesabi Iron Range north of Duluth. During that 1919-20 school year he gave instruction in physical training and manual training as well as coaching football and basketball. The young man found life in Biwabik fascinating because of the many different ethnic groups in the town. Later, Stong set a novel (The Iron Mountain) and a children's book (Honk: The Moose) in the Iron Range. After a year in Minnesota's far north, he went to New York City for graduate work in English at Columbia University. The years 1921 to 1923 found 
him in Neodesha, Kansas, where he taught English, coached the debate team, and managed school publications. While spending two and one half years in southeastern Kansas, Stong took correspondence courses in education from the University of Kansas. Then, in 1924, Stong returned to Des Moines to teach journalism at Drake and coach debate. ${ }^{1}$

Turning from teaching to the practice of journalism, Phil Stong went to work as a reporter and editorial writer for the Des Moines Register. During all of this time, he was striving to become a creative writer. As early as November 1921 he had a story in The Midland, an important regional literary magazine edited by John T. Frederick. ${ }^{2}$ In 1925, at age 26, Stong returned to New York, where he worked first as a wire editor for the Associated Press and then as a copy editor and feature writer for the North American Newspaper Alliance. In 1927 he went to Boston to interview Nicola Sacco and Bartolomeo Vanzetti just before their execution, an experience he considered one of the most important in his life. ${ }^{3}$ Later, he was with the magazines Liberty and Editor and Publisher, and then Sunday feature editor of the newspaper the New York World, and finally an advertising writer for Young and Rubicam.

On November 8, 1925, at the time he moved to New York, Phil Stong married Virginia Maude Swain, who was also a newspaper reporter. Stong credited her with encouraging him in his writing. The year before his death, Stong reminisced about the beginnings of his most famous novel: "I was working in the publicity department of one of the few good advertising firms in the world when Mrs. Stong suggested that I do

\footnotetext{
${ }^{1}$ The basic facts of Phil Stong's life can be found in Clarence A. Andrews, "Stong, Phil(lip Duffield)," Dictionary of American Biography, Supplement Six, 1956-60, 603-04. See also, Phil Stong, If School Keeps (New York: Stokes, 1940), an unusual autobiography that recounts Stong's schooling, his career as a teacher, and his opinions on education.

${ }^{2}$ Phil Stong, "Hymeneal," The Midland, 7 (November 1921), 370-85.

${ }^{3}$ Phil Stong, "The Last Days of Sacco and Vanzetti," in The Aspirin Age, 1919-1941, ed. by Isabel Leighton (New York: Simon and Schuster, 1949), 169-89, and Fred Somkin, "How Vanzetti Said Goodbye," The Journal of American History, 68 (September 1981), 298-312.
} 
something about my native State's great harvest festival, the Fair." 4 This happened in the summer of 1931 . On July 28 , he wrote to the "Folks" back in Iowa: "I've finally got a novel coming in fine shape. I've done 10,000 words on it in three days and I get more enthusiastic every day. . . . I hope I can hold up this time. I always write 10,000 swell words and then go to pieces. ${ }^{\prime \prime 5}$

State fairs were a subject that Phil Stong knew well. For several years his grandfather had been superintendent of the swine division at the Iowa State Fair. Then, while a reporter with the Des Moines Register, Stong was assigned to cover the evening stock shows at the fair. American agricultural fairs were and still are a combination of education and festivity: exhibitions, demonstrations, competition for premiums, horse racing, grandstand entertainment, and carnival attractions. Iowa held its first state fair in 1854, and for some time fairs were held at various locations around the state before permanently settling in Des Moines. As years went by, the fairs drew larger crowds and became more elaborate. Judging of livestock, for instance, became more scientific when professors from Iowa State University took over from amateur committees. For rural folks, the fair was a wonderful opportunity to get away from home, see old friends, and meet new people. Many families camped at the fair as they had done at tent Chautauquas in small towns.

The plot of State Fair is simple. Each member of the Frake family attends the fair with a purpose. Father Abel Frake, farmer and stock breeder, wants his Hampshire boar "Blue Boy" to win the sweepstakes. Abel's wife Melissa wants to win blue ribbons for her pickles. Son Wayne wants revenge at the hoop-la stand, a carnival game in which prizes are won by tossing rings. And daughter Margy wants some fun. Wayne

\footnotetext{
${ }^{4}$ Letter, Phil Stong to Cyril Clemens, February 23, 1956, Manuscript Letters Collection, Special Collections Department, The University of Iowa Libraries, Iowa City.

${ }^{5}$ Letter, Phil Stong to "Folks," July 28, 1931, Phil Stong Papers, Cowles Library, Drake University, Des Moines.
} 
and Margy are also looking for romantic adventures. "The Frakes had stepped for a moment into a fantasy." 6

State Fair is very much an lowa book, filled with incidents and details from the author's own life. While the setting of a state fair in the early part of the twentieth century is accurately portrayed, Stong was of course writing as a novelist and not as a historian. There is undeniably an element of make-believe in State Fair. The author was creating an artistic representation of the fair, not presenting the literal truth. As always, Stong was bubbling with whimsy and humor.

The novel appeared in the late spring of 1932 and was widely reviewed. ${ }^{7}$ While most of the notices were favorable, Iowans tended to think that the Frake children were "loose." In a letter to his college roommate, Stong wrote: "Iowa generally felt that Iowa girls wouldn't do such things." 8 At the end of the year a good review in England prompted this comment: ". . . and even the wounds left in my hide by the Tama Tribune and the What Cheer Gazette are beginning to heal over nicely."9 Another pleasant emollient was money. After publication by the Century Company, the book became a Literary Guild Selection and was reprinted in 1933 by Grosset and Dunlap. Subsequently, there were foreign editions, paperbacks, and even an Armed Services edition. In the fall of 1932, Hollywood made a film of the book with Will Rogers starring as Abel Frake. In 1945 the book became a musical motion picture with Vivian Blaine and Jeanne Crain and some memorable songs by Rodgers and Hammerstein such as "Grand Night for Singing" and

\footnotetext{
${ }^{6}$ Phil Stong, State Fair (New York: The Century Co., 1932), 252.

7 Among the major reviews were Louis Kronenberger, "The Brighter Side of Farm Life," The New York Times Book Review (May 8, 1932) 6; Robert Cantwell, "This Side of Paradise," The New Republic, 71 (July 6, 1932), 215-16; Garreta Busey, "Middle West New Style," New York Herald Tribune Books (May 8, 1932) 1-2; and Arthur Ruhl, "Iowa, Old Style," The Saturday Review of Literature, 8 (May 7, 1932), 713.

${ }^{8}$ Letter, Phil Stong to Harvey Davis, September 19, 1932, Manuscript Letters Collection, Special Collections Department, The University of Iowa Libraries, Iowa City.

${ }^{9}$ Letter, Phil Stong to "Folks," December 9, 1932, Stong Papers, Drake University.
} 
"It Might as Well be Spring." Finally, a film with a Texas setting was released in 1962. With the income he earned from State Fair, Stong was able to buy his mother's family farm, the George C. Duffield Estate called "Linwood Farm," just north of the ghost town of Pittsburg on the west side of the Des Moines River. The author made many improvements on the farm which he then rented to a tenant.

After his success with State Fair, Phil Stong went on to write more than forty books, many of them set in the Keosauqua area. When not writing adult fiction, he tried his hand at children's books. "I use the pieces to clear my throat between books to remind myself that direction, simplicity, and suspense are the sine qua non of all narrative writing." 10 His favorite among his own books was Buckskin Breeches (1937), a historical novel based on his grandfather Duffield's memories of frontier Iowa. ${ }^{11}$ Phil Stong died at his home in rural western Connecticut in 1957, but his most famous book lives on in Iowa's literary heritage.

\footnotetext{
10 "Phil Stong" in More Junior Authors (New York: H. W. Wilson, 1963), 197.

${ }^{11}$ Louie W. Attebery, "Phil Stong's Buckskin Breeches," The Palimpsest, 68 (Winter 1987), 184-88.
} 